\title{
FORMS OF PHOSPHORUS IN AN OXISOL UNDER DIFFERENT SOIL TILLAGE SYSTEMS AND COVER PLANTS IN ROTATION WITH MAIZE ${ }^{(1)}$
}

\author{
Arminda Moreira de Carvalho(2), Mercedes Maria da Cunha Bustamante ${ }^{(3)}$, Zayra Azeredo \\ do Prado Almondes ${ }^{(4)}$ \& Cícero Célio de Figueiredo ${ }^{(5)}$
}

\begin{abstract}
SUMMARY
Phosphorus fractions play a key role in sustaining the productivity of acidsavanna Oxisols and are influenced by tillage practices. The aim of this study was to quantify different $P$ forms in an Oxisol (Latossolo Vermelho-Amarelo) from the central savanna region of Brazil under management systems with cover crops in maize rotation. Three cover crops (Canavalia brasiliensis, Cajanus cajan (L.), and Raphanus sativus $\mathrm{L}$.) were investigated in maize rotation systems. These cover crops were compared to spontaneous vegetation. The inorganic forms $\mathrm{NaHCO}_{3}-\mathrm{iP}$ and $\mathrm{NaOH}-\mathrm{iP}$ represented more than half of the total $\mathrm{P}$ in the samples collected at the depth of 5-10 cm during the rainy season when the maize was grown. The concentration of inorganic $\mathrm{P}$ of greater availability $\left(\mathrm{NaHCO}_{3}-\mathrm{iP}\right.$ and $\left.\mathrm{NaOH}-\mathrm{iP}\right)$ was higher in the soil under no-tillage at the depth of 5-10 cm during the rainy season. Concentrations of organic $P$ were higher during the dry season, when the cover crops were grown. At the dry season, organic $P$ constituted $70 \%$ of the labile $P$ in the soil planted to $C$. cajan under no-tillage. The cover crops were able to maintain larger fractions of $P$ available to the maize, resulting in reduced $P$ losses to the unavailable pools, mainly in no-tillage systems.
\end{abstract}

Index terms: organic matter, available phosphorus, phosphorus sequential fractionation, organic phosphorus, inorganic phosphorus.

\footnotetext{
(1) Received for publication on May 13, 2013 and approved on March 13, 2014.

(2) Researcher, Embrapa Cerrados. BR 020, km 18. CEP 73010-970 Planaltina (DF), Brazil. E-mail: arminda.carvalho@embrapa.br

(3) Professor, Ecology Department, Universidade de Brasília - UnB. Campus Universitário Darcy Ribeiro. CEP 70910-900 Brasília (DF), Brazil. E-mail: mercedes@unb.br

(4) MS student, UnB. E-mail: zayralmondes@hotmail.com

(5) Professor, Faculdade de Agronomia e Medicina Veterinária, UnB. E-mail: cicerocf@unb.br
} 


\title{
RESUMO: FORMAS DE FÓSFORO EM LATOSSOLO SOB DIFERENTES SISTEMAS DE MANEJO E DE PLANTAS DE COBERTURA EM ROTAÇÃO COM MILHO
}

\begin{abstract}
Frações de P desempenham papel fundamental na manutenção da produtividade dos Latossolos ácidos do Cerrado e são influenciadas pelas práticas de manejo. O objetivo deste estudo foi quantificar as diferentes formas de Pem um Latossolo Vermelho-Amarelo do Cerrado, sob sistemas de manejo com plantas de cobertura em rotação com milho. Três plantas de cobertura (Canavalia brasiliensis, Cajanus cajan (L.) e Raphanus sativus L.) foram estudadas. Essas plantas de coberturas foram comparadas com vegetação espontânea. As formas inorgânicas $\mathrm{NaHCO}_{3}-i \mathrm{P}$ e $\mathrm{NaOH}$-iP representaram mais da metade do $\mathrm{P}$ total nas amostras coletadas na profundidade de $5-10 \mathrm{~cm}$, durante a estação chuvosa, quando o milho foi cultivado. A concentração de Pinorgânico de maior disponibilidade $\left(\mathrm{NaHCO}_{3}\right.$-iPe $\mathrm{NaOH}$-iP) foi maior no solo sob plantio direto na profundidade de 5-10 cm, durante a estação chuvosa. As concentrações de Porgânico foram maiores durante a estação seca, quando as plantas de cobertura foram cultivadas. Nessa estação, o P orgânico constituiu $70 \%$ do P lábil no solo plantado com C. cajan, sob plantio direto. As plantas de cobertura foram capazes de manter maiores frações de $P$ disponivel para o milho, resultando em redução de perdas de P para compartimentos indisponíveis, principalmente em sistemas de plantio direto.
\end{abstract}

Termos de indexação: matéria orgânica, fósforo disponível, fracionamento sequencial de fósforo, fósforo orgânico, fósforo inorgânico.

\section{INTRODUCTION}

The dominant soils in the Central region of Brazil are dystrophic Oxisols, and conventional agricultural practices, especially tillage systems, have led to erosion, with losses of organic matter (OM) and nutrients (Bayer et al., 2006). In this region, $\mathrm{P}$ is one of the elements whose scarcity most limits crop development. However, in more weathered soils, the decomposition and mineralization of forest litter and soil OM make up the primary sources of $\mathrm{P}$ since mineral $\mathrm{P}$ is retained mostly in less available forms (Vincent et al., 2010).

Chemical fractionation represents an approximation of the biological and geochemical compartments that regulate the dynamics of organic and inorganic $\mathrm{P}$ in the soil. In sequential analysis, $\mathrm{P}$ in solution and labile $\mathrm{P}$ are removed first; then the more stable (recalcitrant) forms of this nutrient in the soil are also removed. In sequential extraction, organic and inorganic $\mathrm{P}$ fractions are determined in soil samples subjected to the extractors with different levels of bioavailability, which makes it possible to establish the approximate ratio among labile, nonlabile, and occluded $\mathrm{P}$, and then infer $\mathrm{P}$ availability in the soil (Tiessen \& Moir, 1994; Cardoso et al., 2003; Resende et al., 2010).

Hence, $\mathrm{P}$ availability is dependent on the production system used, including crop residue and fertilizer management, which is directly related to the type of tillage system used, conventional and notillage (Araújo et al., 1996; Neufeldt et al., 2000; Tiecher et al., 2012; Mishra et al., 2012; Wyngaard et al., 2012).

Compared to other major nutrients, $\mathrm{P}$ is by far the least mobile and available to plants in most soil conditions, particularly in Oxisols, and is therefore likely to be greatly affected by tillage. Mechanical manipulation of soil during tillage may increase the chance of contact between soil solution or fertilizerderived $\mathrm{P}$ and exposed soil particles, facilitating the formation of stable insoluble $\mathrm{P}$ compounds (Picone et al., 2003). Tillage, notably 'no-tillage', affects some chemical characteristics related to soil acidity that may influence $P$ availability, plant growth, and yield (Ernani et al., 2002). Organic matter and $\mathrm{P}$ in greater quantities accumulate in the top few centimeters under no-tillage, compared to conventional tillage (Basamba et al., 2006; Mishra et al., 2012).

In crop rotation systems with cover crops, if residue production is high and if the soil is not revolved, the availability of $\mathrm{P}$ is strongly associated with the C cycle (Rheinheimer et al., 2000). The release of this nutrient from crop residues is dependent on the quantity and quality of OM, the decomposition process, and environmental conditions. Organic acids (oxalic, malonic, and piscidic) exuded by the roots of some plants such as Cajanus cajan can also remove adsorbed $\mathrm{P}$ from $\mathrm{Fe}$ and $\mathrm{Al}$ of the soil (Ae et al., 1991).

In a long-term experiment with six winter crops, the application of phosphate fertilizer in no-tillage rows increased inorganic $\mathrm{P}$ in the labile and moderately labile forms; and soil disturbance in conventional tillage redistributed the applied $\mathrm{P}$ to the deeper layers, increasing the moderately labile $\mathrm{P}$ concentration in the subsurface layers. Black oat and blue lupin were the most efficient P-recyclers, and under no-tillage they increased the labile $\mathrm{P}$ content in the soil surface layers (Tiecher et al., 2012). 
The aim of this study was to evaluate the effect of different soil tillage systems (conventional and notillage) and the effect of different cover crops with maize rotation on the $\mathrm{P}$ forms in an Oxisol in the central savanna region of Brazil.

\section{MATERIAL AND METHODS}

The study was conducted at the Embrapa Cerrados experimental station, Planaltina, DF, Brazil ( $15^{\circ} 36^{\prime} 37^{\prime \prime} \mathrm{S}$ and $\left.47^{\circ} 44^{\prime} 36^{\prime \prime} \mathrm{W}\right)$. The soil was classified as a Latossolo Vermelho-Amarelo (Embrapa, 2006) or Typical Acrustox (Soil Survey Staff, 2006). The texture and chemical characterization of the soil are shown in table 1 . The climate is Aw (tropical with rainy summer) according to the Köppen classification. During the period under study, monthly pluvial precipitation ranged from null (July 2002) to $252 \mathrm{~mm}$ (January 2003). The monthly mean average temperature oscillated from $19^{\circ} \mathrm{C}$ (June 2003) to $27^{\circ} \mathrm{C}$ (March 2003).

At the beginning of the experiment (January 1997), the area was fertilized with $180 \mathrm{~kg} \mathrm{ha}^{-1}$ of $\mathrm{P}_{2} \mathrm{O}_{5}$ $\left(79 \mathrm{~kg} \mathrm{ha}^{-1} \mathrm{de} \mathrm{P}\right)$ as fertilization for soil amendment. Before sowing, maintenance fertilization of $178 \mathrm{~kg} \mathrm{ha}^{-1}$ of $\mathrm{P}_{2} \mathrm{O}_{5}\left(78 \mathrm{~kg} \mathrm{ha}^{-1}\right.$ of $\left.\mathrm{P}\right)$ was applied in the form of single superphosphate, $49.8 \mathrm{~kg} \mathrm{ha}^{-1}$ of $\mathrm{K}$ as potassium chloride, and $50 \mathrm{~kg} \mathrm{ha}^{-1}$ of a micronutrient source (7 \% Zn, $2.5 \%$ Bo, $1 \% \mathrm{Cu}, 4 \% \mathrm{Fe}, 4 \% \mathrm{Mn}, 0.1 \% \mathrm{Mo}$, and $0.1 \% \mathrm{Co}$ ). Maintenance fertilization was repeated every year in accordance with soil analysis (CFSG, 1988), from the beginning of the experiment until 2002. The experiment was set up in a randomized complete block design with a split plot arrangement with three replications. Cover crops were sown into whole plots $(12 \times 30 \mathrm{~m})$ at the end of each rainy season following by a maize crop in both conventional tillage (with

Table 1. Soil physical and chemical characteristics for the 0-20 cm depth of a Typical Acrustox in the Cerrado region of Brazil (mean for $n=20$ samples)

\begin{tabular}{lr}
\hline Characteristic & Mean \\
\hline Clay $\left(\mathrm{g} \mathrm{kg}^{-1}\right)$ & 513 \\
$\mathrm{Loam}\left(\mathrm{g} \mathrm{kg}^{-1}\right)$ & 186 \\
Sand $\left(\mathrm{g} \mathrm{kg}^{-1}\right)$ & 301 \\
$\mathrm{pH}\left(\mathrm{H}_{2} \mathrm{O}\right)(1: 2,5)$ & 6.20 \\
Organic matter $\left(\mathrm{g} \mathrm{kg}^{-1}\right)$ & 23.60 \\
$\mathrm{Al}^{3+}\left(\mathrm{cmol}_{\mathrm{c}} \mathrm{kg}^{-1}\right)$ & 0.01 \\
$\mathrm{H}+\mathrm{Al}\left(\mathrm{cmol}_{\mathrm{c}} \mathrm{kg}^{-1}\right)$ & 3.34 \\
$\mathrm{Ca}^{2+}+\mathrm{Mg}^{2+}+\mathrm{K}^{+}\left(\mathrm{cmol}_{\mathrm{c}} \mathrm{kg}^{-1}\right)$ & 3.40 \\
$\mathrm{CEC}\left(\mathrm{cmol}_{\mathrm{c}} \mathrm{kg}^{-1}\right)$ & 6.80 \\
$\mathrm{Base} \mathrm{saturation}(\%)$ & 50 \\
$\mathrm{P}(\mathrm{mg} \mathrm{kg}$ & \\
\hline
\end{tabular}

incorporation of plant residues using a disk plow and harrow) and no-tillage subplots $(12 \times 15 \mathrm{~m})$. Plots and subplots were separated by a $1 \mathrm{~m}$ border. Fertilizers were incorporated with the plant residues before sowing the maize, using a disk harrow in subplots under tillage or applied to the soil surface under no-tillage. The experiment was conducted from 1997 to 2002, and the cover crops were sown in the same area (plot) every year.

\section{Cover crops/maize systems and soil sampling}

The following cover crop species were used in rotation with maize: Canavalia brasiliensis $\mathrm{M}$. and Benth (Leguminosae), Cajanus cajan (L.) Millsp cv. Caqui (Leguminosae) and Raphanus sativus L (Brassicaceae). The control treatment consisted of natural fallow. Cover crops were planted in March (end of rainy season). Seeds were distributed $(3 \mathrm{~cm}$ deep) in rows (spaced at $0.5 \mathrm{~m}$ ) using a no-till planter.

Cover crops were cut at flowering and remained on the soil surface until sowing maize at the beginning of the rainy season. In the tilled subplots, plant residues were incorporated with a disk plow $(20 \mathrm{~cm}$ depth). Maize was sown at the beginning of the rainy season (Nov 7, 2002) at a density of 55,000 plants ha-1 and a row spacing of $0.9 \mathrm{~m}$.

In 2002 , four years after the beginning of the experiment, during the dry season, soil samples were collected at the depth of $0-5 \mathrm{~cm}$ in trenches measuring $45 \times 3 \times 5 \mathrm{~cm}$. At the depth of $5-10 \mathrm{~cm}$, samples were collected at three points, from the bottom to the top of the trenches. The samples consisted of the homogenization of eight sub-samples (trenches) in each subplot, at the depth of $5-10 \mathrm{~cm}$. The three points collected from the eight trenches added up to 24 subsamples per subplot. The soil samples were then dried, ground, and sieved to $2 \mathrm{~mm}$ for sequential analysis of $P$.

\section{Analysis of soil $\mathbf{P}$ fractions}

A sequential extraction of $\mathrm{P}$ (Tiessen \& Moir, 1994) was carried out in duplicate with extractors in the following order: $0.5 \mathrm{~mol} \mathrm{~L}^{-1} \mathrm{NaHCO}_{3}(\mathrm{pH}=8.5)$, $0.1 \mathrm{~mol} \mathrm{~L}^{-1} \mathrm{NaOH}$, hot concentrated $\mathrm{HCl}$, and residue digestion with $\mathrm{H}_{2} \mathrm{SO}_{4}$ (residual fraction). Resin extraction was not performed, so resin $\mathrm{P}$ is included in the $\mathrm{NaHCO}_{3}$ fraction. The $1 \mathrm{~mol} \mathrm{~L}^{-1} \mathrm{HCl}$ step was also skipped because weathered soils such as those at this site generally do not contain $\mathrm{P}$ as part of the primary minerals extracted with $1 \mathrm{~mol} \mathrm{~L}^{-1} \mathrm{HCl}$. Phosphorus concentrations in all fractions were determined with molybdenum blue chemistry (Murphy \& Riley, 1962). Certified Aldrich Phytic acid and ERA Nutrients, and PotableWatR with Orthophosphate $\mathrm{P}$ were used as quality control standards for determinations of the organic and inorganic P solution, respectively. NIST Montana Soil, Standard Reference material 2711, was used as the soil total $\mathrm{P}$ quality control standard. 
Centrifuge tubes with the remaining soil were placed to dry and one part of the weighed dry soil was added to tubes for digestion. Then, $5 \mathrm{~mL}$ of sulfuric acid (with salicylic acid as a catalyzer) and $4 \mathrm{~mL}$ of $\mathrm{H}_{2} \mathrm{O}_{2}$ were added to these tubes, which were placed inside a block digester at $320{ }^{\circ} \mathrm{C}$ for $30 \mathrm{~min}$. The supernatant was analyzed for concentration of residual $\mathrm{P}$. Concentrations of organic $\mathrm{P}$ were calculated by the difference between total $\mathrm{P}$ and inorganic $\mathrm{P}$.

Labile $\mathrm{P}$ was considered the sum of the organic (oP) and inorganic (iP) forms extracted with $\mathrm{NaHCO}_{3}$ and $\mathrm{NaOH}$. Recalcitrant $\mathrm{P}$ was represented by the organic and inorganic fractions extracted with $\mathrm{HCl}$ (heated and concentrated) and obtained by sulfuric acid/hydrogen peroxide digestion (Neufeldt et al., 2000; Cardoso et al., 2003).

\section{Statistical analysis}

An analysis of variance was performed for the study with data repeated over space and time to evaluate the effects of the cover crops (plots), types of residue management (subplots), soil depths (sub subplots) and the seasons of collection (sub sub subplots). These analyses and their respective deployments of significant interactions were performed using the SAS program (SAS, 2002), applying the PROC MIXED procedure.

\section{RESULTS}

\section{The inorganic fraction in conventional and} no-tillage systems with cover crops

Average content of the $\mathrm{NaHCO}_{3}$-iP fraction was higher in soil subjected to the no-tillage system at the depth of $5-10 \mathrm{~cm}$ and in the samples collected in the rainy season (Table 2). The soil under conventional and no-tillage systems yielded higher concentrations in the samples collected from the depth of $5-10 \mathrm{~cm}$, with the management system presenting differences in relation to the content of the $\mathrm{NaHCO}_{3}$-iP fraction only at this depth $(p<0.001)$.

Higher concentrations of the $\mathrm{NaOH}-\mathrm{iP}$ fraction were observed in the rainy season and at the depth of $5-10 \mathrm{~cm}$ (Table 2). The types of management systems led to differences in respect to the high contents of the $\mathrm{NaOH}-\mathrm{iP}$ fraction $(\mathrm{p}<0.07)$, which were found only in the soil samples from the $5-10 \mathrm{~cm}$ layer and in the samples collected during the rainy season.

During the dry season, lower contents of the HCliP fraction were obtained in the soil samples from plots planted to C. cajan and, subsequently, under spontaneous vegetation (Table 2). Soil planted to $C$. brasiliensis and $R$. sativus yielded higher concentrations of this fraction $(\mathrm{p}<0.01)$ during the dry season in relation to collection performed during the rainy season (181 and $175 \mathrm{mg} \mathrm{kg}^{-1}$ respectively). In the dry season, these concentrations were higher in the samples from the depth of $0-5 \mathrm{~cm}$ while, during the rainy season, higher levels of $\mathrm{HCl}-\mathrm{iP}$ were obtained in the samples collected at the depth of $5-10 \mathrm{~cm}$. Significant individual effects from plant species, from the types of management practices, and from the season of collection were also observed concerning this iP fraction.

In the plots subjected to the conventional system with $C$. cajan, the samples yielded the highest value of residual $P$ during the dry season (Table 2). In the plots of the no-tillage system, residual $\mathrm{P}$ content was the highest in samples collected during the rainy season from areas planted to C. brasiliensis. Under conventional tillage, the soil presented the highest level of residual $P$ in the 5-10 cm layer, and under the no-tillage system, in the $0-5 \mathrm{~cm}$ layer. The average value of residual $\mathrm{P}$ was higher in the soil samples collected in the rainy season, under both management types.

\section{The organic fraction in conventional and no- tillage systems with cover crops}

In general, concentrations of the $\mathrm{NaHCO}_{3}-\mathrm{oP}$ fraction (Table 3) were low, with average contents ranging from $7.4 \mathrm{mg} \mathrm{kg}^{-1}$ (rainy season) to $26 \mathrm{mg} \mathrm{kg}^{-1}$ (dry season). In the conventional tillage system, the highest values of this fraction were obtained during the dry season from soil planted to C. brasiliensis and, in the no-tillage system, from areas planted to $R$. sativus.

Concentrations in the $\mathrm{NaOH}-\mathrm{oP}$ fraction were higher in soil subjected to the conventional tillage system and spontaneous vegetation during the rainy season, as well as under the no-tillage system for $R$. sativus and $C$. brasiliensis, also during the rainy season (Table 3). Considering the average $\mathrm{NaOH}$-oP content, samples collected during the rainy season resulted in higher values for this part of the oP fraction.

Contents of the $\mathrm{HCl}-\mathrm{oP}$ fraction were low, with average values ranging from 19 to $32 \mathrm{mg} \mathrm{kg}^{-1}$ (Table $3)$. The lowest contents were found during the dry season in soil samples from areas planted to $R$. sativus and spontaneous vegetation subjected to no-tillage and conventional systems, respectively.

\section{Labile $P$ content}

Higher average content of labile P (sum of the organic and inorganic $\mathrm{P}$ fractions, extracted by $\mathrm{NaHCO}_{3}$ and $\mathrm{NaOH}$ ) was obtained in the samples collected in the rainy season in relation to the dry season (Table 3). The highest value of labile $\mathrm{P}$ was determined at the depth of $5-10 \mathrm{~cm}$ during the rainy season.

When soil was collected in the dry season, the content of recalcitrant $\mathrm{P}\left(357 \mathrm{mg} \mathrm{kg}^{-1}\right)$ was $55 \%$ of 
Table 2. Concentrations of the inorganic phosphorus fractions and of residual phosphorus in a soil with a cover crop under conventional and no-tillage systems at two depths and two seasons (dry and rainy)

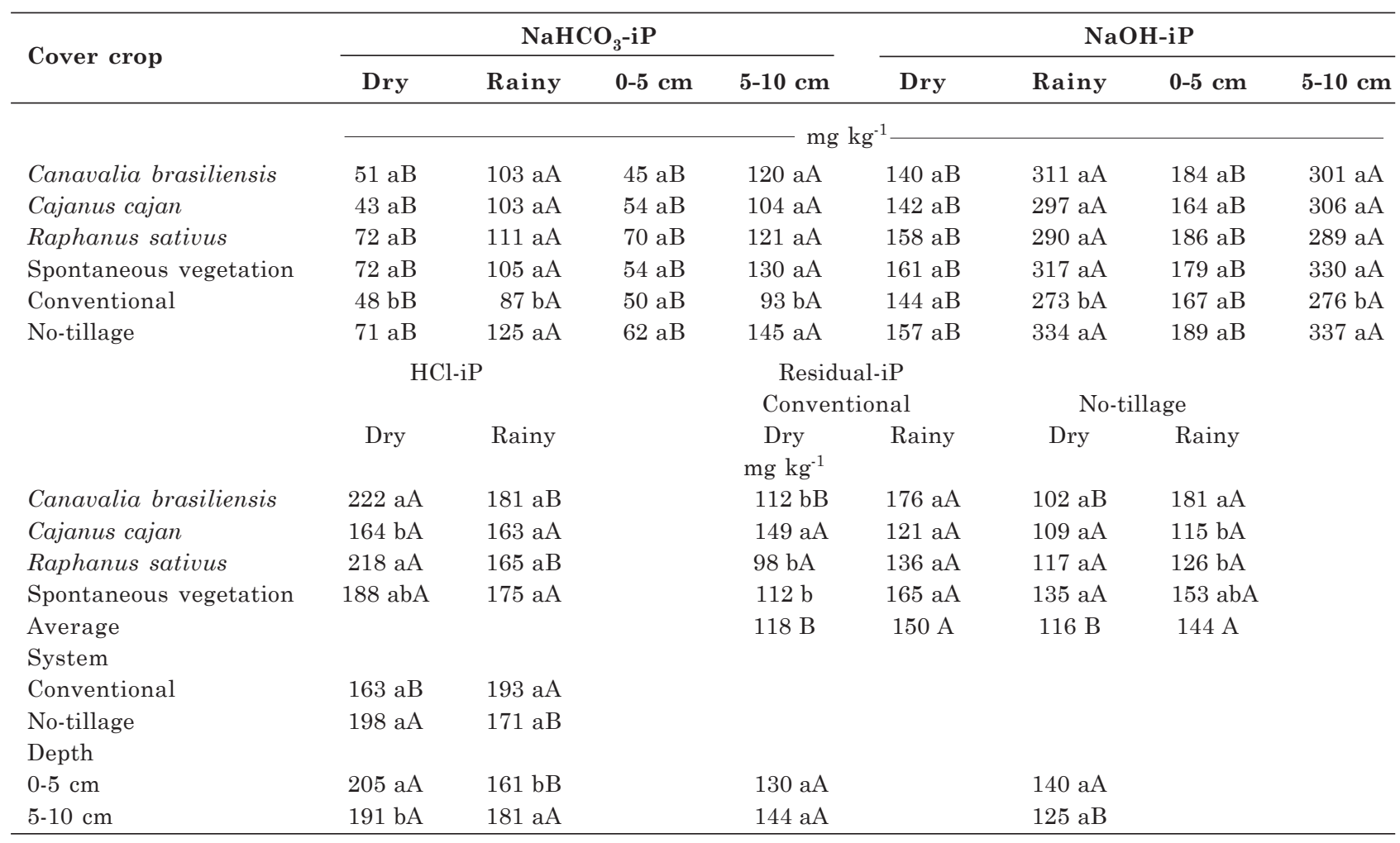

Means followed by the same letter, lower case in the column and upper case in the row, in each fraction, are not significantly different at $\mathrm{p}<0.05$ according to Tukey's test.

Table 3. Concentrations of the organic, labile, recalcitrant fractions and total phosphorus in a soil with cover crops under conventional and no-tillage systems over two seasons (dry and rainy)

\begin{tabular}{|c|c|c|c|c|c|c|c|c|c|c|c|c|}
\hline \multirow{3}{*}{ Cover crop } & \multicolumn{4}{|c|}{$\mathrm{NaHCO}_{3}-\mathrm{oP}$} & \multicolumn{4}{|c|}{$\mathrm{NaOH}-\mathrm{oP}$} & \multicolumn{4}{|c|}{ HCl-oP } \\
\hline & \multicolumn{2}{|c|}{ Conventional } & \multicolumn{2}{|c|}{ No-tillage } & \multicolumn{2}{|c|}{ Conventional } & \multicolumn{2}{|c|}{ No-tillage } & \multicolumn{2}{|c|}{ Conventional } & \multicolumn{2}{|c|}{ No-tillage } \\
\hline & Dry & Rainy & Dry & Rainy & Dry & Rainy & Dry & Rainy & Dry & Rainy & Dry & Rainy \\
\hline & & & & & & & $\mathrm{g}^{-1}-$ & & & & & \\
\hline Canavalia brasiliensis & $38 \mathrm{aA}$ & $11 \mathrm{aB}$ & $9.3 \mathrm{bA}$ & $8.3 \mathrm{aA}$ & $52 \mathrm{aA}$ & $77 \mathrm{aA}$ & $58 \mathrm{aB}$ & $137 \mathrm{aA}$ & $23 \mathrm{aA}$ & $21 \mathrm{aA}$ & $49 \mathrm{aA}$ & $8.8 \mathrm{aB}$ \\
\hline Cajanus cajan & $23 \mathrm{abA}$ & $6.2 \mathrm{aB}$ & $26 \mathrm{abA}$ & $3.4 \mathrm{aB}$ & $40 \mathrm{aB}$ & $108 \mathrm{aA}$ & $45 \mathrm{aA}$ & 89 bA & $68 \mathrm{aA}$ & $25 \mathrm{aA}$ & $44 \mathrm{aA}$ & $19 \mathrm{aA}$ \\
\hline Raphanus sativus & $28 \mathrm{abA}$ & $4.9 \mathrm{aB}$ & $33 \mathrm{aA}$ & $6.9 \mathrm{aB}$ & $61 \mathrm{aB}$ & $113 \mathrm{aA}$ & $74 \mathrm{aB}$ & $153 \mathrm{aA}$ & $4 \mathrm{bA}$ & $18 \mathrm{aA}$ & $15 \mathrm{aA}$ & $26 \mathrm{aA}$ \\
\hline Spontaneous vegetation & $16 \mathrm{bA}$ & $7.5 \mathrm{aA}$ & $25 \mathrm{abA}$ & $16 \mathrm{aA}$ & $64 \mathrm{aB}$ & $159 \mathrm{bA}$ & $44 \mathrm{aB}$ & $101 \mathrm{abA}$ & $34 \mathrm{aA}$ & $33 \mathrm{aA}$ & $2 \mathrm{bA}$ & $21 \mathrm{aA}$ \\
\hline \multirow[t]{5}{*}{ Average } & $26 \mathrm{~A}$ & $7.4 \mathrm{~B}$ & $23 \mathrm{~A}$ & $8.6 \mathrm{~B}$ & $54 \mathrm{~B}$ & $114 \mathrm{~A}$ & $55 \mathrm{~B}$ & $120 \mathrm{~A}$ & $32 \mathrm{~A}$ & $24 \mathrm{~A}$ & $27 \mathrm{~A}$ & $19 \mathrm{~B}$ \\
\hline & \multirow{2}{*}{\multicolumn{2}{|c|}{ Total P }} & \multicolumn{6}{|c|}{ Labile P } & \multicolumn{4}{|c|}{ Recalcitrant P } \\
\hline & & & & \multicolumn{2}{|c|}{ Conventional } & \multicolumn{2}{|c|}{ No-tillage } & & \multicolumn{2}{|c|}{ Conventional } & \multicolumn{2}{|c|}{ No-tillage } \\
\hline & Dry & Rainy & & Dry & Rainy & Dry & Rainy & & Dry & Rainy & Dry & Rainy \\
\hline & \multicolumn{12}{|c|}{$\mathrm{mg} \mathrm{kg}^{-1}$} \\
\hline Canavalia brasiliensis & $544 \mathrm{aB}$ & $763 \mathrm{aA}$ & & $263 \mathrm{aB}$ & $434 \mathrm{aA}$ & $276 \mathrm{aB}$ & $628 \mathrm{aA}$ & & $351 \mathrm{aA}$ & $372 \mathrm{aA}$ & $368 \mathrm{aA}$ & $378 \mathrm{aA}$ \\
\hline Cajanus cajan & $535 \mathrm{aB}$ & $742 \mathrm{aA}$ & & $264 \mathrm{aB}$ & $459 \mathrm{aA}$ & $240 \mathrm{aB}$ & $548 \mathrm{aA}$ & & $379 \mathrm{aA}$ & $297 \mathrm{bB}$ & $321 \mathrm{bA}$ & $309 \mathrm{bA}$ \\
\hline Raphanus sativus & $744 \mathrm{aA}$ & $613 \mathrm{aB}$ & & $267 \mathrm{aB}$ & $463 \mathrm{aA}$ & $391 \mathrm{aB}$ & $621 \mathrm{aA}$ & & $420 \mathrm{aA}$ & $316 \mathrm{abA}$ & $357 \mathrm{aA}$ & $321 \mathrm{abA}$ \\
\hline Spontaneous vegetation & $615 \mathrm{aB}$ & $761 \mathrm{aA}$ & & $296 \mathrm{aB}$ & $579 \mathrm{aA}$ & $318 \mathrm{aB}$ & $558 \mathrm{aA}$ & & $331 \mathrm{aA}$ & $364 \mathrm{aA}$ & $329 \mathrm{bA}$ & $357 \mathrm{aA}$ \\
\hline System & & & & & & & & & & & & \\
\hline Conventional & $550 \mathrm{~B}$ & $693 \mathrm{~A}$ & & & & & & & & & & \\
\hline No-tillage & $603 \mathrm{~B}$ & $812 \mathrm{~A}$ & & & & & & & & & & \\
\hline Depth & & & & & & & & & & & & \\
\hline $0-5 \mathrm{~cm}$ & $571 \mathrm{aB}$ & $640 \mathrm{bA}$ & & $293 \mathrm{aA}$ & $367 \mathrm{bA}$ & & & & $324 \mathrm{bB}$ & & $349 \mathrm{aA}$ & \\
\hline $5-10 \mathrm{~cm}$ & $582 \mathrm{aB}$ & $865 \mathrm{aA}$ & & $286 \mathrm{aB}$ & $706 \mathrm{aA}$ & & & & $356 \mathrm{aA}$ & & $336 \mathrm{bA}$ & \\
\hline
\end{tabular}

Means followed by the same letter, lower case in the column and upper case in the row, in each fraction, are not significantly different at $\mathrm{p}<0.05$ according to Tukey's test. 
labile P. The level of recalcitrant $\mathrm{P}\left(297 \mathrm{mg} \mathrm{kg}^{-1}\right)$ was lower in soils planted to $C$. cajan, under the conventional system, and collected in the rainy season.

\section{Total phosphorus}

Total $\mathrm{P}$ obtained from sulfuric acid/hydrogen peroxide digestion varied from 550 to $865 \mathrm{mg} \mathrm{kg}^{-1}$, corresponding to the dry and rainy seasons (Table 3 ). It varied from $617 \mathrm{mg} \mathrm{kg}^{-1}$ (dry season and depth of $0-5 \mathrm{~cm}$ ) to $1,042 \mathrm{mg} \mathrm{kg}^{-1}$ (rainy season and depth of $5-10 \mathrm{~cm})$.

The management system, soil depth and the season of collection exercised significant effects on the total $\mathrm{P}$ content. The total $\mathrm{P}$ content found in soil growing $R$. sativus was high during the dry season $(\mathrm{p}<0.01)$ while in soils planted to the other plant species, a higher total P content was observed in samples collected in the rainy season (Table 3). The highest total $\mathrm{P}$ concentrations were obtained in samples collected in the rainy season and at the depth of 5-10 $\mathrm{cm}$ in the no-tillage system.

\section{Validation of the results obtained from sequential fractionation}

The difference between the total $\mathrm{P}$ from sequential extraction and total $\mathrm{P}$ from sulfuric acid/hydrogen peroxide digestion was less than $10 \%$ for most of the samples analyzed. The most accentuated variations between these two extractions were observed in few soil samples $(<10 \%)$, collected in the rainy season. This allowed for validation of the results obtained from the sequential fractionation in this study.

\section{DISCUSSION}

\section{Effect of conventional tillage and no-tillage systems on the $\mathbf{P}$ fraction}

The highest concentrations of the $\mathrm{NaHCO}_{3}$-iP and $\mathrm{NaOH}-\mathrm{iP}$ fractions were found in the soil samples collected in the rainy season at the depth of $5-10 \mathrm{~cm}$ under no-tillage systems. These results could be related to the season and to how the fertilizer was applied. The no-till planter used to sow the maize has a mechanism to insert fertilizer under the seed, resulting in an application (at the rate of $65.5 \mathrm{~kg} \mathrm{ha}^{-1}$ of $\mathrm{P}$ ) below the 5-cm layer, concentrating this element at the depth of $5-10 \mathrm{~cm}$. After five years, localized application of a high quantity of $\mathrm{P}$ led to saturation of the adsorption sites, resulting in a high compartment of labile $\mathrm{P}$ in the no-tillag e system, especially in the $5-10 \mathrm{~cm}$ soil layer (Rheinheimer et al., 2000; Wyngaard et al., 2012; Tiecher et al., 2012).

The predominance of inorganic forms $(\mathrm{NaOH}-i \mathrm{P}$ fraction) in total $\mathrm{P}$ from the soil collected during the rainy season (Table 2), represented 28 and $40 \%$ at the depths of 0-5 and 5-10 cm, respectively. These results were also observed in other studies (Araújo et al., 1996; Conte et al., 2003; Wyngaard et al., 2012 ), in which this fraction was also considered to be predominant in cultivation systems with fertilization. The high quantities of iP extracted with the $\mathrm{NaOH}$ extractor indicate the $\mathrm{P}$ applied that was not promptly absorbed by the plants. At the depth of $5-10 \mathrm{~cm}$ and in the soil collected at the maturation stage of the maize (rainy season), the two most available fractions ( $\mathrm{NaHCO}_{3}-\mathrm{iP}, \mathrm{NaOH}-\mathrm{iP}$ ) represented $55 \%$ of the total Ps. In soil collected during the dry season, the $\mathrm{NaHCO}_{3}$-iP and $\mathrm{NaOH}$ iP fractions make up $35 \%$ of the total $\mathrm{P}$, thus acting as an available source of P 10 months after application of the fertilizer. Lilienfein et al. (2000) observed that the $\mathrm{NaOH}-\mathrm{iP}$ fraction was the most concentrated fraction in the soy/maize rotation under the no-tillage system. Conte et al. (2003) also verified that, in the no-tillage system, the moderately labile iP fraction $(\mathrm{NaOH}-\mathrm{iP})$ was the major sink for the applied $\mathrm{P}$, and that participation of the labile fractions of iP was in direct relation to the quantity of $\mathrm{P}$ added to the soil.

The high concentration of iP in the fractions of rapid availability (Table 2), such as the $\mathrm{NaHCO}_{3}$-iP fraction and, especially, the $\mathrm{NaOH}$-iP fraction, indicates that there was no effect of the cover crops on increasing the availability of this element in the soil. The soil adsorption sites were saturated mainly in the samples from the no-tillage plots collected during the rainy season, reducing the impacts of the chemical and biological mechanisms (Ae et al., 1990; Reinheimer et al., 2000; Cardoso et al., 2003; Tiecher et al., 2012) that act to release adsorbed $P$ to the constituents of the clay. The action of the cover crops was more accentuated in relation to the iP. concentrated $\mathrm{HCl}$ fractions and residual $\mathrm{P}$ when the level of $\mathrm{P}$ in the soil was low, i.e., in the samples collected during the dry season, after the export of nutrients in the form of maize grain and ten months after fertilizer application (Table 2).

Basamba et al. (2006) showed that the $\mathrm{P}$ fractions were also generally higher in no-till treatments. Results from this study indicate that the rotational systems (maize-soybean-green manure and maizepastures) improved the soil conditions for implementing no-till or minimum tillage systems in a savanna Oxisol.

\section{Effect of cover plants on $P$ fraction}

The highest level of extracted oP in the $\mathrm{NaHCO}_{3}$ oP fraction in the soil samples collected from plots subjected to the conventional system increased biomass production (Carvalho et al., 2009). Greater decomposition of these plants (Carvalho et al., 2008) may have favored the synthesis of $\mathrm{oP}$ compounds and the availability of this element in its organic forms. However, in the no-tillage system, the formation of 
organic compounds may have been inhibited in the samples planted to $C$. brasiliensis $\left(9.0 \mathrm{mg} \mathrm{kg}^{-1} \mathrm{P}\right)$ due to the limited contact of its residues with the soil, in agreement with Rheinheimer et al. (1999), who related soil oP availability to the incorporation of biomass. The higher level of the $\mathrm{NaHCO}_{3}$-oP fraction under the no-tillage system and $R$. sativus is possibly due to the capacity of this cover crop in concentrating nutrients in its tissue, especially $\mathrm{P}$ (Carvalho et al., 2008). Wyngaard et al. (2012) indicated that oP is affected by management practices, and Qiao (2012) reported that the percentage of total $\mathrm{P}$ present as $\mathrm{iP}$ was affected by the crop in the agrosystem. Tiecher et al. (2012) observed that black oat and blue lupin were the most efficient P-recyclers and, in no-tillage, they increased the labile $\mathrm{P}$ content in the soil surface layers. Thus, with the accumulation of crop residues on the soil surface, as observed in the present study, the release of labile $\mathrm{P}$ was favored, due to the high level of decomposition of this cover crop in the no-tillage system (Carvalho et al., 2008; 2009). The higher concentration of this organic fraction in the samples collected in the dry season $\left(26 \mathrm{mg} \mathrm{kg}^{-1} \mathrm{P}\right)$ in relation to the samples collected in the rainy season $\left(8 \mathrm{mg} \mathrm{kg}^{-1} \mathrm{P}\right)$ is in agreement with the inverse relationship obtained between oP and the quantities of phosphate fertilizers added to the soil (Araújo et al., 1996; Conte et al., 2003).

The markedly higher levels of the NaOH-oP fraction in the soil samples collected in the rainy season in relation to those collected in the dry season for the no-tillage system with the use of $C$. brasiliensis and $R$. sativus, and under no-tillage and conventional systems of spontaneous vegetation, are attributed to the biomass produced by the occurrence of regrowth, especially in the case of $C$. brasiliensis and spontaneous vegetation (Sodré Filho et al., 2004). The decomposition of plant residues in these species (Carvalho et al., 2008; 2009) in the presence of moisture may have favored this organic form of $\mathrm{P}$. Chemical fertilization also affected the level of $\mathrm{NaOH}$-oP obtained from the samples collected during the rainy season (three months after the sowing of the maize) with relative participation of $10 \%$ of the total fractions of samples from the $0-5 \mathrm{~cm}$ layer in the soil under the no-tillage system and with spontaneous vegetation, and up to $25 \%$ with the use of $R$. sativus. In relation to the samples collected at the depth of $5-10 \mathrm{~cm}$, the variation of this proportion was $8 \%$ in the no-tillage system with growth of C. cajan, and up to $19 \%$ in soils subjected to the conventional system and spontaneous vegetation. According to Rheinheimer et al. (1999), the oP may occur linked to organic colloids by highly stabilized $\mathrm{Fe}$ and $\mathrm{Al}$ bonds; however, Makarov et al. (1997) questioned the importance of $\mathrm{P}-\mathrm{Fe}(\mathrm{Al})$-humus linkages since the synthetic complex (P-Fe-humus) is stable at $\mathrm{pH}$ 1.5.

\section{CONCLUSIONS}

1. The inorganic forms of greater availability $\left(\mathrm{NaHCO}_{3}-\mathrm{iP}\right.$ and $\left.\mathrm{NaOH}-\mathrm{iP}\right)$ represented more than half of the total $\mathrm{P}$ in samples collected at the depth of $5-10 \mathrm{~cm}$, and were highest in the soil at the depth of $5-10 \mathrm{~cm}$ subjected to the no-tillage system, both during the rainy season.

2. In the dry season, organic $P$ constitutes $70 \%$ of the labile $\mathrm{P}$ in the soil planted to C. cajan under notillage $(0-5 \mathrm{~cm})$ and conventional systems $(5-10 \mathrm{~cm})$.

3 . The results obtained indicate that the use of cover plants, especially under adequate conditions for plant biomass production and synchronization between their decomposition and the use of $\mathrm{P}$ by the following crop, can promote the desorption of this element which accumulates in recalcitrant forms.

4. Phosphorus appears to be more efficiently and gradually reduced in the soil when applied as fertilizer, which is a non-renewable and exhaustible resource.

5 . The cover plants were able to maintain larger fractions of $\mathrm{P}$ available to agricultural crops, thereby reducing $\mathrm{P}$ losses to the unavailable pools, especially in the no-tillage system.

\section{LITERATURE CITED}

AE, N.; ARIHARA, J. \& OKADA, K. Phosphorus uptake mechanism of pigeon pea grown in Alfisols and Vertisols. In: JOHANSEN, C.; LEE, K. \& SAHRAWAT, K.L., eds. Phosphorus nutrition of grain legumes in the semi-arid tropics. Patancheru, ICRISAT, 1991. p.91-98.

ARAÚJO, A.G.; AYARZA, M.A.; FRIESEN, D.K. \& VILELA, L. Frações orgânicas e inorgânicas de fósforo em um solo de Cerrado sob diferentes sistemas de preparo. In: PEREIRA, R.C. \& NASSER L.C.B., eds. Biodiversity and sustainable production of food and fibers in the tropical savannas'. Brasília, Embrapa-CPAC, 1996. p.319-322.

BASAMBA, T.A.; BARRIOS, E.; AMÉZQUITA, E.; RAO, I.M. \& SINGH, B.R. Tillage effects on maize yield in a Colombian savanna Oxisol: Soil organic matter and $\mathrm{P}$ fractions. Soil Till. Res., 91:131-142, 2006.

BAYER, C.; MARTIN-NETO, L.; MIELNICZUK, J.; PAVINATO, A. \& DIECKOW, J. Carbon sequestration in two Brazilian Cerrado soils under no-till. Soil Till. Res., 86:237-245, 2006.

CARDOSO, I.M.; JANSSEN, B.H.; OENEMA, O. \& KUYPER, T.W. Phosphorus pools in Oxisols under shaded and unshaded coffee systems on farmers' fields in Brazil. Agrofor. Syst., 58:55-64, 2003.

CARVALHO, A.M.; BUSTAMANTE, M.M.C.; GERALDO JUNIOR, J. \& VIVALDI, L.J. Decomposition of plant residues in Latosol under corn crop and cover crops. R. Bras. Ci. Solo, 32:2831-2838, 2008. 
CARVALHO, A.M.; BUSTAMANTE, M.M.C.; ALCÂNTARA, F.A.; RESCK, I.S. \& LEMOS, S.S. Characterization by solid-state CPMAS 13C NMR spectroscopy of decomposing plant residues in conventional and no-tillage systems in Central Brazil. Soil Till. Res., 101:100-107, 2009.

COMISSÃO DE FERTILIDADADE DE SOLOS DE GOIÁS CFSG. Recomendações de corretivos e fertilizantes para Goiás: $5^{\mathrm{a}}$ aproximação. Goiânia, 1988. 101p.

CONTE, E.; ANGHINONI, I. \& RHEINHEIMER, D.S. Phosphorus accumulation fractions in a clayey Oxisol in relation to phosphate doses under no-tillage. R. Bras. Ci. Solo, 27:893-900, 2003.

EMPRESA BRASILEIRA DE PESQUISA AGROPECUÁRIA EMBRAPA. Centro Nacional de Pesquisa em Solos. Sistema brasileiro de classificação de solos. Rio de Janeiro, 2006. 306p.

ERNANI, P.R.; BAYER, C. \& MAESTRI, L. Corn yield as affected by liming and tillage system on an acid Brazilian Oxisol. Agron. J., 94:305-309, 2002.

LILIENFEIN, J.; WILCKE, W.; AYARZA, M.A.; VILELA, L.; LIMA, S.D.C. \& ZECH, W. Chemical fractionation of phosphorus, sulphur, and molybdenum in Brazilian savannah Oxisols under different land use. Geoderma, 96:31-46, 2000.

MAKAROV, M.I.; MALYSHEVA, T.I.; HAUMAIER, L.; ALT, H.G. \& ZECH, W. The forms of phosphorus in humic and fulvic acids of Alpine Soils in the Northern Caucasus. Geoderma, 80:61-73, 1997.

MISHRA, A.; CABRERA, M.L. \& REMA, J.A. Phosphorus fractions in poultry litter as affected by flue-gas desulphurization gypsum and litter stacking. Soil Use Manage., 28:27-34, 2012.

MURPHY, J. \& RILEY, J.P. A modified single solution method for the determination of phosphate in natural waters. Anal. Chim. Acta, 27:31-36, 1962.

NEUFELDT, H.; SILVA, J.E.; AYARZA, M.A. \& ZECH, W. Land-use effects on phosphorus fractions in Cerrado Oxisols. Biol. Fertil. Soils, 31:30-37, 2000.

PICONE, L.I.; ZAMUNER, E.C.; BERARDO, A. \& MARINO, M.A. Phosphorus transformations as affected by sampling date, fertilizer rate and phosphorus uptake in a soil under pasture. Nutr. Cycl. Agroecosyst., 67:225-232, 2003.
QIAO, S.M.Y. Distribution of inorganic and organic phosphorus fractions in two phosphorus-deficient soils as affected by crop species and nitrogen applications. Commun. Soil Sci. Plant Anal., 43:631-644, 2012.

RESENDE, J.C.F.; BUSTAMANTE, M.M.C.; MARKEWITZ, D.; KLINK, C.A. \& DAVIDSON, E.A. Phosphorus cycling in a small watershed in the Brazilian Cerrado: Impacts of frequent burning. Biogeochemistry, 105:105-118, 2010.

RHEINHEIMER, D.S.; ANGHINONI, I. \& KAMINSKI, J. Depletion of inorganic phosphorus fractions by successive extraction with resin in different soils and management systems. R. Bras. Ci. Solo, 24:345-354, 2000.

RHEINHEIMER, D.S.; CASSOL, P.C.; KAMINSKI, J. \& ANGHINONI, I. Fósforo orgânico do solo. In: SANTOS, G.A. \& CAMARGO, F.A.O., eds. Fundamentos da matéria orgânica do solo ecossistemas tropicais e subtropicais. Porto Alegre, Metrópole, 1999. p.227-244.

SAS Institute. SAS User's guide Statistics. 5.ed. Cary, 2000. 943p.

SODRÉ FILHO, J.; CARDOSO, N.A.; CARMONA, R. \& CARVALHO, A.M. Phytomass and soil cover of sequential crops after maize in Cerrado region. Pesq. Agropec. Bras., 39:327-334, 2004.

SOIL SURVEY STAFF. Keys to soil taxonomy. 10 ed. Washington, DC, USDA-Natural Resources Conservation Service, 2006.

TIECHER, T.; RHEINHEIMER, D.S.; KAMINSKI, J. \& CALEGARI, A. Forms of inorganic phosphorus in soil under different long term soil tillage systems and winter crops. R. Bras. Ci. Solo, 36:271-281, 2012.

TIESSEN, H. \& MOIR, J.O. Characterization of available P by sequential extraction. In: CARTER, M.R. \& GREGORICH, E.G., eds. Soil sampling and methods of analysis, Boca Raton, CRC Press, 1994. P.75-86.

VINCENT, A.G.; TURNER, B.L. \& TANNER, E.V.J. Soil organic phosphorus dynamics following perturbation of litter cycling in a tropical moist forest. Eur. J. Soil Sci., 61:48$57,2010$.

WYNGAARD, N.; ECHEVERRÌA, H.E.; VIDAURRETA, A.; PICONE, L.I. \& DIVITO, G.A. Carbon and phosphorus in soil particulate fraction: Effect of continuous agriculture, tillage and fertilization. Geophys. Res. Abstr., 14:3377$3390,2012$. 